\title{
AIDS-Related Kaposi Sarcoma
}

National Cancer Institute

\section{Source}

National Cancer Institute. AIDS-Related Kaposi Sarcoma. NCI Thesaurus. Code C3992.

The most aggressive form of Kaposi sarcoma. It presents in patients who are infected with the human immunodeficiency virus. It can affect the skin and internal organs. 